\title{
AKAP9/BRAF Fusion Gene
}

National Cancer Institute

\section{Source}

National Cancer Institute. AKAP9/BRAF Fusion Gene. NCI Thesaurus. Code C99593.

A fusion gene ( $\sim 4.6 \mathrm{~kb})$ that results from a paracentric chromosomal inversion inv(7) (q21-22q34) which fuses exon 8 of the AKAP9 gene to exon 9 of the BRAF gene. This fusion is associated with papillary thyroid carcinoma. 